\title{
The $\alpha$ Form of Human Tryptase Is the Predominant Type Present in Blood at Baseline in Normal Subjects and Is Elevated in Those with Systemic Mastocytosis
}

\author{
Lawrence B. Schwartz, ${ }^{\star}$ Kentaro Sakai, ${ }^{*}$ Timothy R. Bradford, ${ }^{*}$ Shunlin Ren, ${ }^{*}$ Burton Zweiman ${ }^{\ddagger}$ Alexandra S. Worobec, ${ }^{\$}$ \\ and Dean D. Metcalfes \\ *Division of Rheumatology, Allergy and Immunology, Department of Medicine, Virginia Commonwealth University, Richmond, Virginia \\ 23298; ${ }^{\ddagger}$ Division of Allergy and Immunology, Department of Medicine, University of Pennsylvania School of Medicine, Philadelphia, \\ Pennsylvania 19104; and ${ }^{8}$ Allergic Diseases Section, Laboratory of Clinical Investigation, National Institute of Allergy and Infectious \\ Diseases, National Institutes of Health, Bethesda, Maryland 20892
}

\begin{abstract}
Tryptase, a protease produced by all mast cells, was evaluated as a clinical marker of systemic mastocytosis. Two sandwich immunoassays were evaluated, one which used the mAb G5 for capture, the other which used B12 for capture. The B12 capture assay measured both recombinant $\alpha$ - and $\beta$-tryptase, whereas the G5 capture assay measured primarily recombinant $\beta$-tryptase. G5 binds with low affinity to both recombinant $\alpha$-tryptase and tryptase in blood from normal and nonacute mastocytosis subjects, and binds with high affinity to recombinant $\beta$-tryptase, tryptase in serum during anaphylaxis, and tryptase stored in mast cell secretory granules. B12 recognizes all of these forms of tryptase with high affinity. As reported previously, during systemic anaphylaxis in patients without known mastocytosis, the ratio of B12- to G5-measured tryptase was always $<5$ and approached unity (Schwartz L. B., T. R. Bradford, C. Rouse, A.-M. Irani, G. Rasp, J. K. Van der Zwan and P.-W. G. Van Der Linden J. Clin. Immunol. 14:190-204). In this report, most mastocytosis patients with systemic disease have B12-measured tryptase levels that are elevated $(>20$ $\mathrm{ng} / \mathrm{ml}$ ) and are at least 10-fold greater than the corresponding G5-measured tryptase level. Most of those subjects with B12-measured tryptase levels of $<20 \mathrm{ng} / \mathrm{ml}$ had only cutaneous manifestations. The B12 assay for $\alpha$-tryptase and $\beta$ tryptase, particularly when performed in conjunction with the G5 assay for $\beta$-tryptase, provides a more precise measure of mast cell involvement than currently available assessments, a promising potential screening test for systemic mastocytosis and may provide an improved means to follow disease progression and response to therapy. ( $\mathrm{J}$. Clin. Invest. 1995. 96:2702-2710.) Key words: tryptase $\bullet$ mast cell $\bullet$ mastocytosis • anaphylaxis
\end{abstract}

\section{Introduction}

Systemic mastocytosis is a hyperplastic disease of mast cells $(1,2)$. Target organs may include skin, liver, spleen, lymph

Address correspondence to Lawrence B. Schwartz, Virginia Commonwealth University, P. O. Box 980236, Richmond, VA 23298. Phone: 804-828-9685; FAX: 804-828-0283; E-mail: Ischwartz@ruby.vcu.edu

Received for publication 2 May 1995 and accepted in revised form 24 August 1995.

The Journal of Clinical Investigation, Inc.

Volume 96, December 1995, 2702-2710 nodes, bowel, and bone marrow. Several forms of the disease have been documented that vary in severity. Based upon a mastocytosis consensus conference, one classification scheme labels mastocytosis as indolent, that associated with hematologic disorders or aggressive (2); this being the classification used in the current study. The diagnosis of mastocytosis currently requires a tissue biopsy showing a pathologic increase in numbers of mast cells. Bone marrow biopsies in patients with systemic disease generally show characteristic lesions consisting of paratrabecular collections of spindle-shaped mast cells intermixed with fibroblasts, mononuclear cells, and eosinophils. However, in the face of mild, often nonspecific signs and symptoms, such as flushing, fatigue, intermittent diarrhea, or peptic ulcers in the absence of classical urticaria pigmentosa, clinicians often do not feel compelled to perform a bone marrow biopsy. Current treatment strategies are generally limited to treating the complications of systemic mastocytosis (peptic ulcers, itching, hypotension). There is no proven consistent therapy that will reverse mast cell hyperplasia (3), and little progress has been achieved at lowering the mortality from aggressive forms of this disease.

Tryptase, a neutral serine protease, is selectively concentrated in the secretory granules of all mast cells $(4,5)$, including mast cells found in skin lesions of mastocytosis (6). Basophils are the only other cell type with detectable tryptase, but levels are several hundredfold lower than in mast cells, and represent a negligible amount (7). Two immunoassays for measuring tryptase are currently in use in our laboratory and will be referred to as the G5 (8) and B12 (9) immunoassays. The G5 immunoassay used the $\mathrm{G} 5 \mathrm{mAb}$ for capture and the noncompeting G4 mAb for detection. With each immunoassay comparable levels of tryptase can be measured in serum or plasma during insect sting-induced systemic anaphylaxis, where levels correlate to the severity of the clinical reaction (9-11). Tryptase in serum and plasma obtained from healthy control subjects is not detectable by the G5 immunoassay $(<1 \mathrm{ng} / \mathrm{ml})$, whereas the B12 immunoassay reveals that serum and plasma samples from normal subjects contain $\sim 5 \mathrm{ng} / \mathrm{ml}$ of tryptase. This suggests that a different form of tryptase is measured by the B12 immunoassay.

In patients with biopsy proven systemic mastocytosis, $\sim 50 \%$ of the subjects have detectable levels of tryptase in plasma samples obtained during nonacute periods as measured with the G5 immunoassay $(10,12)$. The current study compares tryptase levels measured by the two immunoassays in patients with systemic mastocytosis. As the data will demonstrate the B12 immunoassay reveals markedly elevated levels of tryptase in baseline samples of plasma from patients with mastocytosis compared to controls, and therefore should be considered as a 
screening test for mastocytosis. Evidence also is presented that elevated levels of plasma tryptase are measured by the B12 immunoassay relative to the G5 immunoassay because $\alpha$-tryptase is detected only by the B12 immunoassay, and this is the predominant form of tryptase in samples of blood obtained at baseline.

\section{Methods}

Materials. BSA, Mes, Hepes, Tween 20, 5-bromo-4-chloro-3-indoyl phosphate (BCIP), ${ }^{1}$ nitro blue tetrazolium (NBT), Coomassie brilliant blue, bromophenol blue, dithiothreitol, glycerol (Sigma Chemical Co., St. Louis, MO); alkaline phosphatase-conjugated streptavidin and $\mathrm{N}$ glycosidase $\mathrm{F}$ (Boehringer-Mannheim Biochemicals Corp. Indianapolis, IN); sulfosuccinimidyl-6-(biotinamido) hexanoate (NHS-LC-biotin) (Pierce Chemical Co., Rockford, IL); serum-free Spodoptera frugiperda (Sf-9 cell line) and Sf-900 II serum free media for insect cell culture (SFM) (GIBCO BRL Life Technologies, Inc., Grand Island, NY); pVL1392 and pVL1393 (Pharmingen, San Diego, CA); and AcMNPV linear DNA Transfer Module containing linearized AcMNPV baculovirus DNA and cationic liposomes (Invitrogen Corp., San Diego, CA) were obtained as indicated. Antitryptase mAbs (G5, G3, G4, B12, and B2) and MPC11, an IgG1 of unknown specificity, were prepared and purified as previously described $(9,13)$.

Human subjects. All procedures used to obtain human specimens were approved by the Committee on Human Studies at Virginia Commonwealth University, the Human Subjects Committee of the University of Pennsylvania or the National Institute of Allergy and Infectious Diseases (NIAID) institutional review board at the National Institutes of Health and followed informed consent. Subjects with systemic mastocytosis were diagnosed and categorized using published criteria (2). Subjects were divided into those with indolent mastocytosis (type I, $n$ $=46$ ), mastocytosis with an associated hematologic disorder (type II, $n=5$ ), and aggressive mastocytosis (type III, $n=4$ ). Those with aggressive mastocytosis exhibited mast cell hyperplasia, lymphadenopathy, splenomegaly, and eosinophilia and are anticipated to have rapidly progressive disease leading to death within 4 to $5 \mathrm{yr}$ of diagnosis. Those with indolent mastocytosis were further subdivided into those with cutaneous disease alone (urticaria pigmentosa $[n=12]$ or diffuse cutaneous mastocytosis $[n=1])$, and those with systemic disease and exhibiting mild $(n=3)$, moderate $(n=16)$, and severe $(n=14)$ clinical manifestations based on a single-blinded physician assessment of frequency and signs and symptoms. Signs and symptoms of attacks attributed to release of mast cell mediators included pruritus, flushing, nausea with or without vomiting, crampy abdominal pain with diarrhea, and dizziness to loss of consciousness. Also considered were constitutional signs and symptoms such as fever, weight loss, anorexia, and fatigue. The group labeled mild had attacks no more than once per week and had mild to no diarrhea, no dizziness or loss of consciousness and few, if any, constitutional signs or symptoms. The moderate group had attacks one to three or four times per week with signs and symptoms intermediate in severity between the mild and severe groups. The severe group had attacks daily to several times per week, and exhibited marked constitutional and anaphylactic signs and symptoms noted above. Six control subjects with diseases other than mastocytosis or chronic urticaria were examined, including one each with AIDS, eosinophilic gastroenteritis, idiopathic anaphylaxis (nonacute), active atopic dermatitis, chronic myelomonocytic leukemia, or hypereosinophilic syndrome. Plasma was obtained from blood collected during nonacute periods (except where noted otherwise). Nonacute mastocytosis is defined as a time when signs or symptoms of anaphylaxis (hypotension, dizziness, bronchospasm) were absent. Cells were removed by centrifugation and the plasma stored

1. Abbreviations used in this paper: BCIP, 5-bromo-4-chloro-3-indoyl phosphate; NBT, nitro blue tetrazolium; rh, recombinant human. at $-70^{\circ} \mathrm{C}$. The respective median and range of ages (years), and the percentages of males in each group were 39, 16-65, 67 (disease controls); 28, 0.33-62, 77 (indolent cutaneous mastocytosis); 49, 32-80, 67 (mild indolent); 53, 28-75, 31 (moderate indolent); 44, 0.4273, 36 (severe indolent); 52, 44-64, 60 (mastocytosis with associated hematologic disorder), and 40,18-66, 0 (aggressive mastocytosis). Median age values were not significantly different between these groups except between those with indolent mastocytosis with cutaneous manifestations alone and those with indolent systemic mastocytosis with moderate $(P=0.002)$ and severe $(P=0.04)$ clinical manifestations. Among mastocytosis patients, six of the eight children $(<20 \mathrm{yr}$ old $)$ fell in the category of indolent mastocytosis with only cutaneous involvement. One child had diffuse cutaneous mastocytosis with systemic involvement and another had aggressive mastocytosis. Serum samples collected from 13 control subjects with active, chronic idiopathic urticaria also were examined (two males, $39 \pm 14$ yr old). Values for healthy subjects and those with systemic anaphylaxis were reported previously (9). Two subjects with systemic type I mastocytosis and elevated levels of tryptase by the B12 ELISA were subjected to plasmapheresis after informed consent to obtain quantities of plasma sufficient to permit purification and analysis of tryptase. Calcium was added to form a fibrin clot and the plasmapheresis serum was used as described below.

Expression of recombinant human (rh) tryptase. cDNA constructs containing rh $\alpha$-tryptase (5'-CCAGGATG . . . ATC-3', 1,142 bp) and $\operatorname{rh} \beta$-tryptase ( $5^{\prime}$-CCGTGGCCAGGATG . . . ATC-3', 1,148 bp) sequences, each beginning several nucleotides $5^{\prime}$ of the methionine codon for initiation of translation and ending just prior to the poly-A tail, and each having EcoRI restriction sites introduced at 5' and $3^{\prime}$ ends, were subcloned into pVL1392 and pVL1393 plasmids, respectively, as described (13a). Cotransfection of $1.5 \times 10^{6} \mathrm{Sf}-9$ cells was performed with $1 \mu \mathrm{g}$ of linearized wild-type AcMNPV baculovirus DNA and 3 $\mu \mathrm{g}$ of either pVL1392- $\alpha$-tryptase cDNA or pVL1393- $\beta$-tryptase cDNA transfer vectors using cationic liposomes as instructed by the manufacturer. Sf-9 cells were maintained at $27^{\circ} \mathrm{C}$ in Sf-900 II SFM media. After $6 \mathrm{~d}$ of incubation at $27^{\circ} \mathrm{C}$, the viral supernatants were harvested and viral clones of recombinant baculovirus were purified by three plaque assay screening rounds. The purity of the recombinant virus was confirmed by PCR with recombinant virus primers ( $5^{\prime}$-TTTACTGTTTTCGTAACAGTTTTG-3' and 5'-CAACAACGCACAGAATCTAGC-3' ) as recommended by Invitrogen, and by digestion of the PCR products with BseAI, which cleaves the $\beta$-tryptase, but not the $\alpha$-tryptase PCRproduct. High titer viral stocks $\left(>10^{8}\right.$ plaque-forming units $/ \mathrm{ml}$ ) were produced after three passages in Sf-9 cells infected at low multiplicity of infection ( 0.1 plaque-forming unit/cell).

Expression of rh-tryptase was performed in $50 \mathrm{ml}$ of Sf-9 cells ( 5 $\times 10^{7}$ cells ) grown as adherent cell monolayers in $225 \mathrm{~cm}^{2}$ tissue culture flasks at a multiplicity of infection previously determined to be optimal ( 5 for $\operatorname{rh} \alpha$-tryptase and 2.5 for $\operatorname{rh} \beta$-tryptase) (13a). Maximal levels of rh-tryptase in the culture media were typically reached 3 and $4 \mathrm{~d}$ after infection, respectively. Harvested culture media was subjected to centrifugation at $400 \mathrm{~g}$ for $10 \mathrm{~min}$ at room temperature to remove cells and debris and then applied to a mouse IgG antitryptase (B2 mAb) immunoaffinity column as previously described (13a). B2 recognizes a conformational epitope on the active form of native tryptase, but does not recognize denatured tryptase. Essentially all of the tryptase detectable by the B12 ELISA (9) bound to the column, and was eluted in $10 \mathrm{mM}$ diethanolamine, $\mathrm{pH} 10.0$, containing $0.2 \mathrm{M} \mathrm{NaCl}$ and $50 \%$ ( $\mathrm{vol} / \mathrm{vol}$ ) ethylene glycol at $4^{\circ} \mathrm{C}$. Eluted fractions were immediately neutralized with $1 \mathrm{M}$ Mes, $\mathrm{pH}$ 6.5. The purity of rh-tryptase was assessed by SDSPAGE. After staining with Coomassie brilliant blue R-250 two major diffuse bands at apparent molecular weights between 29,000 and 32,000 were detected for each rh-tryptase. A single $\mathrm{NH}_{2}$-terminal amino acid sequence corresponding to amino acids 19-25 was obtained for each, APAPVQA for rh $\alpha$-tryptase, and APAPGQA for $\operatorname{rh} \beta$-tryptase. Each rhtryptase was enzymatically inactive with synthetic tryptase substrates (tosyl-Gly-Pro-Lys- $p$-nitroanilide and tosyl-arginine methyl ester). Pu- 
rified rh-tryptase was stored frozen at $-70^{\circ} \mathrm{C}$ until used for Western blots or immunoassay experiments.

Immunoassays for tryptase. The mouse mAbs against human tryptase called G5, B12, G3, and G4, each recognizing a distinct epitope, were prepared and purified as described $(8,9,13,14)$. Antibodies to be biotinylated (G5, G3, and G4) were dialyzed in PBS, diluted to a concentration of $2 \mathrm{mg} / \mathrm{ml}$ with $0.1 \mathrm{M} \mathrm{NaHCO}_{3}$, incubated with a fivefold molar excess of NHS-LC-biotin for $\sim 4 \mathrm{~h}$ at room temperature, treated with $1 / 2$ vol of $0.1 \mathrm{M}$ Tris, $\mathrm{pH} 8.0,0.15 \mathrm{M} \mathrm{NaCl}$, concentrated by ultrafiltration, dialyzed against PBS containing $20 \%$ glycerol and $0.05 \%$ $\mathrm{NaN}_{3}$, and stored frozen at $-70^{\circ} \mathrm{C}$. The immunoassay using $\mathrm{G} 5$ for capture and ${ }^{125} \mathrm{I}-\mathrm{G} 4$ for detection (8), and the one using B12 for capture and biotinylated G4 and G3 for detection (9) were each performed as described. In each case, tryptase purified to homogeneity from human lung and measured by the bicinchoninic acid-modified Lowry assay for protein (15) was used as the tryptase standard. Values below the limit of detection for the $\mathrm{G} 5$ immunoassay $(1 \mathrm{ng} / \mathrm{ml}$ ) are shown as 0.5 $\mathrm{ng} / \mathrm{ml}$. All values were above the lower limit for the B12 immunoassay $(0.4 \mathrm{ng} / \mathrm{ml})$.

Purification, deglycosylation, and Western blotting of tryptase. Tryptase was purified from plasma obtained by plasmapheresis by immunoaffinity chromatography on B12-agarose. The resin was incubated with filtered plasma $(0.22 \mu \mathrm{m}$ pore size $)$ overnight at $4^{\circ} \mathrm{C}$, and washed five times with $0.01 \mathrm{M}$ Hepes, $\mathrm{pH} 7.4$, containing $0.15 \mathrm{M} \mathrm{NaCl}$, and $0.05 \% \mathrm{NaN}_{3}$. Bound tryptase was eluted with $0.01 \mathrm{M}$ Tris, $\mathrm{pH} 7.6$, containing $10 \mathrm{mM}$ EDTA and $1 \%$ SDS by heating the mixture at $90^{\circ} \mathrm{C}$ for $10 \mathrm{~min}$. Eluted material was separated from resin and collected by filtration through a Spin-X filter $(0.45 \mu \mathrm{m}$ pore size $)$. Eluted tryptase was concentrated by precipitation in ice-cold $10 \%$ trichloroacetic acid, washed with acetone, dried, and stored at $-20^{\circ} \mathrm{C}$. Tryptase from skin and tryptase from lung, where both $\alpha$ - and $\beta$-tryptase mRNAs are expressed (16), were purified as described by immunoaffinity chromatography on B2-affigel (13). cDNA constructs of rh $\alpha$ - and $\operatorname{rh} \beta$-tryptase were expressed in a baculovirus system, and the protein products were purified from the cell culture media by B2-agarose chromatography (13a). Preparations of purified tryptase destined to be deglycosylated were denatured by heating in a boiling water bath for $10 \mathrm{~min}$, brought to room temperature, and incubated overnight with recombinant $N$-glycosidase $\mathrm{F}$ according to the instructions of the manufacturer (Boehringer Mannheim Biochemicals).

Deglycosylated and unaltered preparations of tryptase were concentrated by precipitation in ice-cold $10 \%$ trichloroacetic acid, washed with ice-cold acetone, air dried, resuspended in SDS sample buffer (1\% SDS, $10 \mathrm{mg}$ dithiothreitol/ml, 5\% glycerol, $2.5 \mathrm{mM}$ Tris, $\mathrm{pH} 8.3,19 \mathrm{mM}$ glycine, $0.1 \%$ [wt/vol] bromophenol blue) and subjected to SDS-PAGE and Western blotting in a semi-dry Pharmacia Phast system (Pharmacia LKB Biotechnology Inc., Piscataway, NJ), or in a Novex X Cell II Mini-Cell system (Novex, San Diego, CA) using biotin-G5 and biotinG3 mAbs, streptavidin-alkaline phosphatase and BCIP/NBT for detection. Samples were transblotted onto $0.2 \mu \mathrm{m}$ supported nitrocellulose in $25 \mathrm{mM}$ Tris, $\mathrm{pH} 8.3$, containing $192 \mathrm{mM}$ glycine and $20 \%$ methanol. Transblotting with the Pharmacia system was performed for $22 \mathrm{~min}$ at $15^{\circ} \mathrm{C}$ and 25 constant $\mathrm{mA}$, and with the Novex system for $30 \mathrm{~min}$ at room temperature and 30 constant volts. Membranes were blocked for

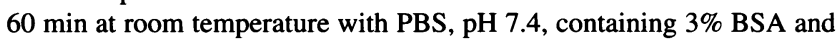
$0.05 \%$ Tween 20 , incubated with biotinylated primary mAb $(0.5 \mu \mathrm{g} /$ $\mathrm{ml}$ ) overnight at $4^{\circ} \mathrm{C}$, washed three times with PBS, incubated with streptavidin-alkaline phosphatase (1:2,000 in $50 \mathrm{mM}$ Tris, $\mathrm{pH} 7.5$, containing $0.15 \mathrm{M} \mathrm{NaCl}, 0.05 \%$ Tween 20 , and $0.05 \% \mathrm{NaN}_{3}$ ) for $60 \mathrm{~min}$ at room temperature, washed and developed with NBT and BCIP as described by the manufacturer. Reactions were stopped by rinsing with PBS containing $20 \mathrm{mM}$ EDTA. For assessing molecular mass, the electrophoretic mobilities of prestained molecular weight markers (GIBCO BRL Life Technology, Inc.) were examined in parallel lanes. Each biotinylated antibody could reveal as little as $20 \mathrm{ng}$ of tryptase purified from lung or skin tissue.

Statistical methods. Comparisons of median values were performed with the Mann-Whitney U test for nonparametric data.

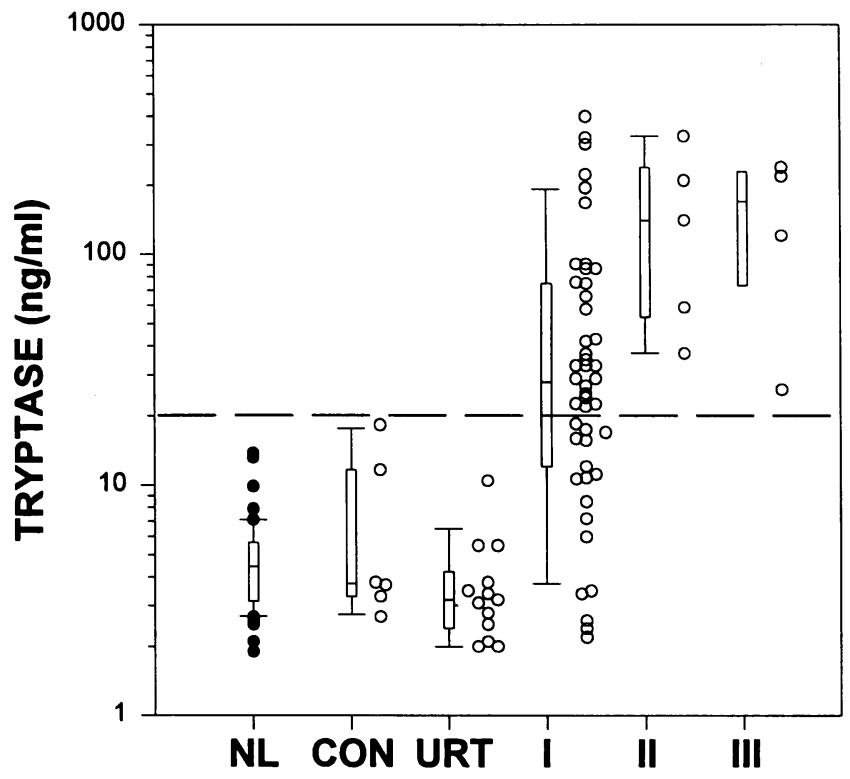

\section{CLINICAL STATUS}

Figure 1. Tryptase levels in blood from subjects with mastocytosis and from controls. Tryptase levels were measured in samples of plasma collected during nonacute periods from patients with mastocytosis having type I, II, or III disease, plasma from controls with unrelated diseases $(C O N)$, serum from patients with chronic idiopathic urticaria when active lesions were present (URT), and serum from healthy subjects $(N L)$ by the B12 immunoassay. Box and whisker plots reflect the median (hatch mark within the rectangle), 25th, and 75th percentiles (upper and lower borders of the box) and whiskers (10th and 90th percentiles). To the right of each box plot individual data points are shown as open circles, except for the NL group, which was published previously (9). Outliers from the NL group are shown as closed circles. Each data point is the mean of duplicate determinations. A horizontal dashed line at 20 $\mathrm{ng} / \mathrm{ml}$ reflects the value chosen as the upper limit for controls.

\section{Results}

Tryptase levels in systemic mastocytosis. Tryptase levels were measured in plasma obtained from subjects with systemic mastocytosis (categories: $\mathrm{I}=$ indolent, $\mathrm{II}=$ with associated hematologic disorder, III = aggressive), and from controls with active urticaria that was chronic and idiopathic (URT), unrelated diseases $(C O N)$ and good health $(N L)$ using the B12 and G5 immunoassays and compared. As shown in Fig. 1, when tryptase levels were measured with the B12 immunoassay, all values in the control groups were $<20 \mathrm{ng} / \mathrm{ml}$, whereas 29 of 46 with type I, 5 of 5 with type II, and 4 of 4 with type III mastocytosis had levels $>20 \mathrm{ng} / \mathrm{ml}$. Each sample in which the tryptase level was $<20 \mathrm{ng} / \mathrm{ml}$ with the B12 immunoassay had a level with the G5 immunoassay that was undetectable except in the urticaria group, in which one subject had tryptase values of $5.5 \mathrm{ng} /$ $\mathrm{ml}$ with the B12 immunoassay and $1.9 \mathrm{ng} / \mathrm{ml}$ with the G5 immunoassay. Also, G5 levels were undetectable when B12 levels were $>20 \mathrm{ng} / \mathrm{ml}$ in eight of those with type I mastocytosis, one with type II and two with type III. Median levels of tryptase measured with the B12 immunoassay were significantly higher in type I (28 ng/ml), type II (141 ng/ml), and type III $(170 \mathrm{ng} / \mathrm{ml})$ mastocytosis than in the control groups with 


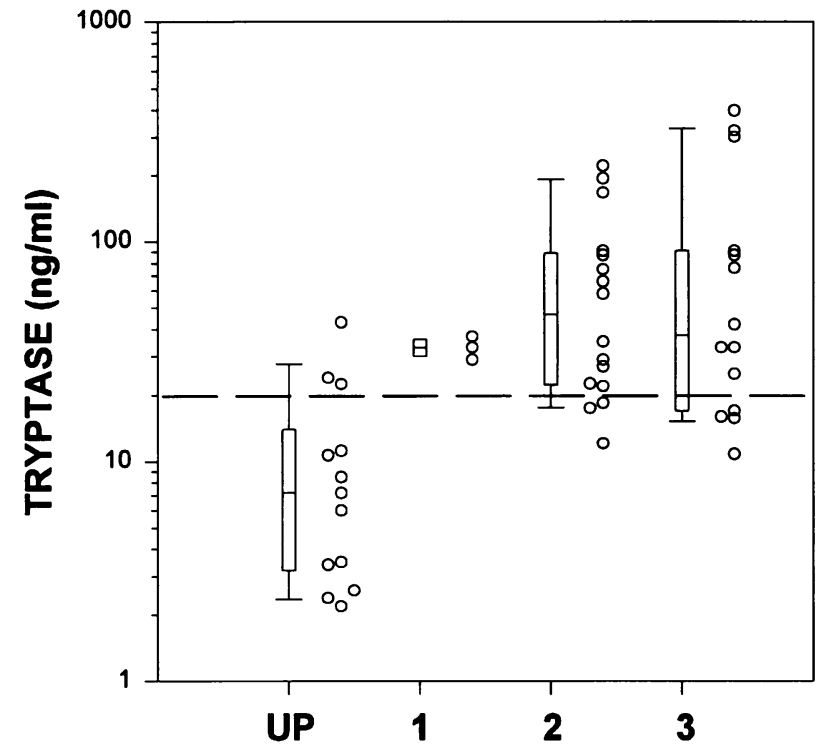

\section{SEVERITY OF INDOLENT MASTOCYTOSIS}

Figure 2. Tryptase levels measured by the B12 immunoassay in plasma from subjects with different clinical severities of indolent mastocytosis. Data from the 46 subjects with indolent mastocytosis shown in Fig. 1 were distributed according to clinical stage and severity. Subcategories include those with only cutaneous involvement (primarily urticaria pigmentosa, $U P, n=13)$, and those with mild $(1, n=3)$, moderate (2, $n=16)$, and severe $(3, n=14)$ systemic disease. Box and whisker plots, and individual data points to the right of each box plot, are shown as described in Fig. 1.

unrelated diseases $(3.8 \mathrm{ng} / \mathrm{ml})$, urticaria $(3.2 \mathrm{ng} / \mathrm{ml})$, and healthy $(4.5 \mathrm{ng} / \mathrm{ml})$ subjects $(P<0.002)$. Although there was a tendency for mastocytosis subjects in category I to have lower tryptase levels than those of categories II and III, comparisons of the median values did not show a statistically significant difference $(P>0.2)$.

Tryptase levels measured with the G5 immunoassay gave substantially lower values than those measured with the B12 immunoassay in mastocytosis subjects and in the control groups. Levels were $<1 \mathrm{ng} / \mathrm{ml}$ in 27 of 46 type I, 2 of 5 type II, and 2 of 4 type III mastocytosis subjects. The $56 \%$ detection rate with the G5 immunoassay is similar to that reported (10). Nevertheless, the median levels for mastocytosis groups II ( $1 \mathrm{ng} /$ $\mathrm{ml})$ and III $(1 \mathrm{ng} / \mathrm{ml})$ were significantly higher than for the control groups $(P<0.05)$. Thus, although median G5 tryptase values for a group of mastocytosis patients should be higher than those of normal subjects, there is extensive overlap of individual values.

To examine whether the level of tryptase varies with disease severity, those with indolent mastocytosis were subdivided into four groups; those with cutaneous involvement alone, and those with mild, moderate, and severe systemic manifestations based upon the frequency and severity of attacks attributed to release of mast cell mediators. Although preliminary results indicate that tryptase levels can increase in association with signs and symptoms attributed to release of mast cell mediators (data not shown), all mastocytosis samples examined in the current study were collected outside of these attacks. Levels determined with the B12 immunoassay are displayed in Fig. 2. Median levels of

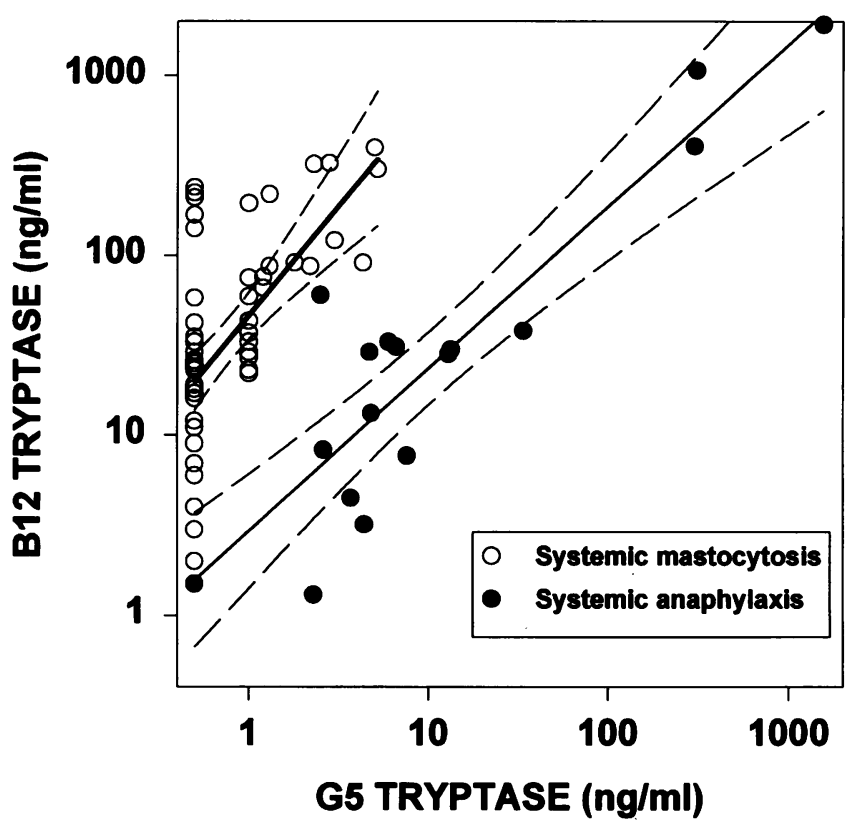

Figure 3. Comparison of G5 and B12 tryptase levels in blood from subjects with nonacute mastocytosis and those with ongoing systemic anaphylaxis. Samples of plasma from the mastocytosis patients depicted in Fig. 1 (open circles) were compared to serum samples taken from subjects undergoing a hypotensive anaphylactic reaction to an insect sting (reported previously in reference 9 ) collected $60 \mathrm{~min}$ after the onset of the clinical response (closed circles). Log scales were used to enable all data to be discerned. Linear regression (solid lines) and $95 \%$ confidence intervals (dashed lines) are shown.

tryptase for the groups with mild, moderate, and severe systemic mastocytosis were not significantly different from one another, irrespective of the immunoassay used. However, the median level for each of these groups was significantly greater than that of the group with cutaneous manifestations alone $(P \leq 0.03)$. Median tryptase levels measured with the G5 immunoassay also were greater in the mild and severe systemic groups than the group with cutaneous manifestations alone, although the overlap between the groups was more extensive (data not shown). Of note is that most of the cutaneous group exhibited B 12 tryptase levels $<20 \mathrm{ng} / \mathrm{ml}$, whereas most of those with systemic disease had levels $>20 \mathrm{ng} / \mathrm{ml}$.

It appeared from the data in Figs. 1 and 2 that the B12 immunoassay was more sensitive at detecting an elevated tryptase level than the G5 immunoassay in subjects with mastocytosis. This contrasts with published data on tryptase levels in serum obtained from patients undergoing systemic anaphylactic reactions to insect stings in which the two immunoassays were comparable in sensitivity (9). To examine this in greater detail, tryptase levels determined by the two immunoassays in plasma from the current nonacute systemic mastocytosis group and in serum from the previously reported systemic anaphylaxis group with hypotension were compared. Published data indicate that tryptase levels in serum are not significantly different from those measured in paired plasma samples (9). In Fig. 3 the tryptase levels measured with each assay are plotted on a log-log scale for anaphylaxis patients (closed circles) and mastocytosis patients (open circles). None of the tryptase values from the systemic anaphylaxis group fell within the $95 \%$ confidence limits of the linear regression line for the tryptase values from the 


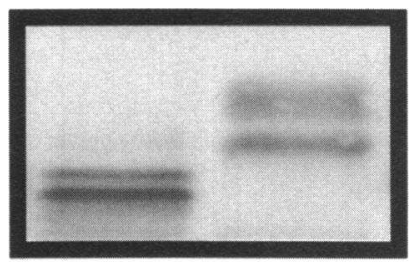

A

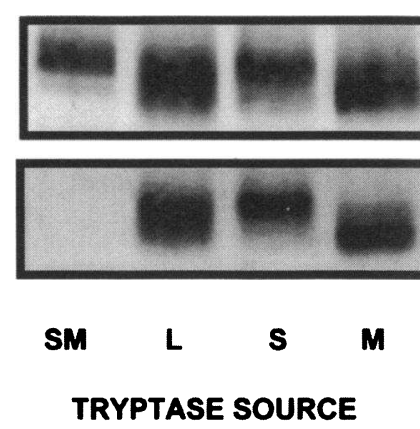

G3 ANTIBODY G5
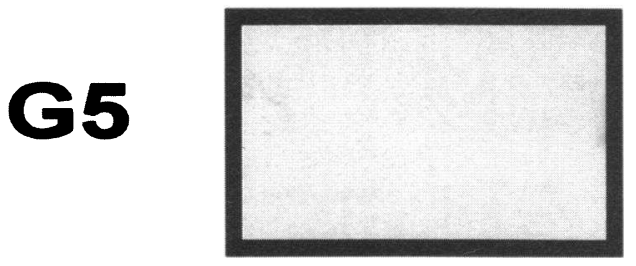

$S_{M}^{*} S M$

Figure 4. Western blots of natural tryptase. (A) Tryptase samples were derived from the serum of a subject with systemic mastocytosis (SM), from normal lung $(L)$, from normal skin $(S)$, and from a cutaneous mastocytoma $(M)$. Each lane contains $2 \mu \mathrm{g}$ of immunoaffinity purified tryptase subjected to SDS-PAGE in a $12.5 \%$ polyacrylamide, $4-\mathrm{cm}$ long Phast gel, blotted onto nitrocellulose, and stained with $0.5 \mu \mathrm{g} / \mathrm{ml}$ of biotin-G5 or biotin-G3. Based on comparisons with GIBCO standards, apparent molecular weights are 32,000,31,500,32,500, and 30,500, respectively. (B) Tryptase, immunoaffinity purified from systemic mastocytosis serum, was deglycosylated with $N$-glycosidase $\mathrm{F}$ ( $S M^{*}$ ) or incubated with buffer alone $(S M)$. These samples (100 ng/lane) were then subjected to SDS PAGE in an 8-cm long Novex $12 \%$ polyacrylamide gel, and Western blotted as in $A$. Higher resolution in $B$ occurred because less protein was loaded per lane and a longer gel was used. Apparent molecular weights of the two SM bands were 35,000 and 32,000 , and the two SM* bands were 30,000 and 28,000 .

mastocytosis group. In terms of tryptase values for an individual subject, during anaphylaxis with hypotension, G5-measured tryptase was $\geq 1 \mathrm{ng} / \mathrm{ml}$ and the ratio of B12- to G5-measured tryptase was $<5$ in all except one of the cases. On the other hand, in subjects with systemic mastocytosis, as shown in Fig. 1 and 2, B12-measured tryptase was $>20 \mathrm{ng} / \mathrm{ml}$ in most cases and G5-measured tryptase was either undetectable or the ratio of B12- to G5-measured tryptase was $>10$.

Tryptase in nonacute mastocytosis plasma lacks the G5 epitope. To examine the mechanism that may account for the differential detection of mastocytosis and anaphylactic tryptase by the B12 and G5 immunoassays, a Western blot of immunoaffinitypurified tryptase from plasmapheresis serum obtained from a patient with systemic mastocytosis was compared to that of tryptase purified from human lung or skin. Two antibodies, G5 and G3, were used for the evaluation. Unlike the B12 mAb, both G5 and G3 detect linear determinants. Furthermore, when G3 is used as a capture antibody with biotin-G4 as detector, values comparable to the B12 immunoassay are obtained with normal serum (Schwartz, L. B., unpublished data). As shown in Fig. $4 A$, characteristic bands of tryptase detected by the G3 $\mathrm{mAb}$ are evident between 30,000 and 35,000 D for tryptase derived from the mastocytosis serum as well as from lung, skin, and a solid cutaneous mastocytoma. In contrast, the G5 mAb labeled tryptase that was derived from tissue, but did not label an amount of tryptase from mastocytosis serum that was clearly labeled by the $\mathrm{G} 3 \mathrm{mAb}$.

Two explanations for the lack of recognition of mastocytosis serum tryptase were considered; the presence of carbohydrate that blocks a G5 epitope, or the absence of the G5 epitope in the primary amino acid sequence. To determine whether carbohydrate could account for the different staining patterns of G5 and G3, purified preparations of tryptase were deglycosylated with $N$-glycosidase F, and then subjected to Western blotting. As shown in Fig. $4 \mathrm{~B}$, deglycosylated tryptase stained with G3 yielded two bands that exhibited slightly faster electrophoretic mobilities $(2,000-7,000 \mathrm{D}$ smaller) and were better resolved than the glycosylated starting material. Incubation with additional $\mathrm{N}$-glycosidase $\mathrm{F}$ or with $\mathrm{O}$-glycosidase did not alter this pattern (data not shown). Also, extensive metabolism of tryptase found in serum or plasma was unlikely, because the apparent molecular weight of mastocytosis serum tryptase was comparable to tissue-derived tryptase. However, the ability of G5 to label only tissue-derived tryptase was not altered by deglycosylation (Fig. $4 \mathrm{~B}$ ). This result was observed with plasmapheresis samples obtained from two different subjects with systemic mastocytosis, one subject having plasma tryptase levels of $270 \mathrm{ng} / \mathrm{ml}$ (B12 assay) and $3.6 \mathrm{ng} / \mathrm{ml}$ (G5 assay), and the second having tryptase levels of $133 \mathrm{ng} / \mathrm{ml}$ (B12 assay) and $4.1 \mathrm{ng} / \mathrm{ml}$ ( $\mathrm{G} 5$ assay). Thus, the failure of G5 to recognize mastocytosis serum or plasma tryptase was not due to metabolism or to carbohydrate blocking groups. The capacity for the G5 immunoassay to detect relatively small amounts of tryptase in mastocytosis sera could reflect the presence of small amounts of $\beta$-tryptase, a weak affinity of G5 for $\alpha$-tryptase, or differences between tryptase that had been denatured and immobilized to tryptase in solution.

The G5 and B12 immunoassays differ in their abilities to recognize rh $\alpha$ - and rh $\beta$-tryptase molecules. At least two genes for tryptase reside in the human genome. One gene corresponds 
A

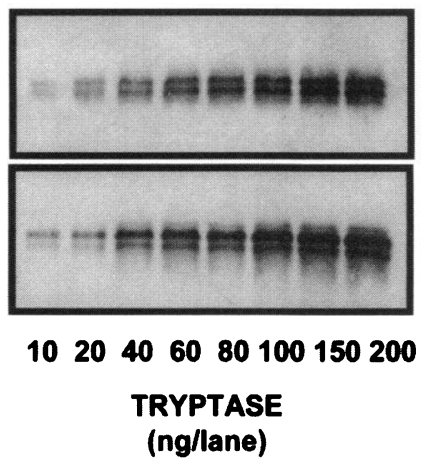

B

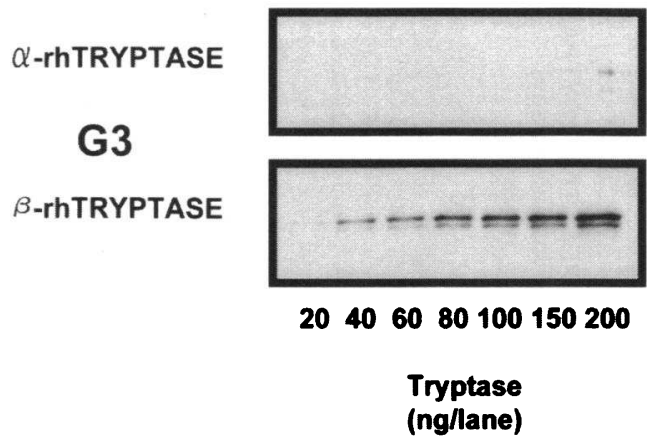

\section{$\alpha$-rhTRYPTASE}

G5

B-rhTRYPTASE

Figure 5. Western blots of $\operatorname{rh} \alpha$-tryptase and $\operatorname{rh} \beta$-tryptase. $(A)$ Dose response of rh $\alpha$ - and $\operatorname{rh} \beta$-tryptase molecules from 10 to 200 ng/lane stained with the G3 mAb at $0.5 \mu \mathrm{g} / \mathrm{ml}$. (B) Dose response of $\mathrm{rh} \alpha$ - and $\mathrm{rh} \beta$-tryptase molecules from 20 to $200 \mathrm{ng} / \mathrm{lane}$ stained with the $\mathrm{G} 5 \mathrm{mAb}$ at 0.5 $\mu \mathrm{g} / \mathrm{ml}$. A $12 \%$ Novex polyacrylamide gel was used in each case. Based on GIBCO molecular weight standards, the two major bands of rh $\alpha$-tryptase exhibited molecular weights of 31,000 and 30,000 , whereas $\operatorname{rh} \beta$-tryptase exhibited two major bands at 31,000 and 29,000 .

to a cDNA encoding $\alpha$-tryptase, which is $93 \%$ identical to the tryptase molecules encoded by the four reported cDNAs that correspond to different forms of $\beta$-tryptase, each of which is $98 \%-99 \%$ identical to the other (17-18a). Although rh $\alpha$ - and $\mathrm{rh} \beta$-tryptase molecules expressed in plaques derived from a $\lambda$ phage expression library were detected previously by both G5 and G3 mAbs $(17,18)$, such a detection system might not reveal affinity differences, because the antigen is markedly concentrated in the plaques. To examine whether differences in affinity for $\alpha$ - and $\beta$-tryptase molecules might account for the immunoassay results, precursor forms of $\operatorname{rh} \alpha$ - and $\operatorname{rh} \beta$-tryptase molecules were expressed in a baculovirus system. Although as anticipated the enzymes did not exhibit enzymatic activity, they were recognized by the B2 and B12 antitryptase mAbs, each of which recognizes a distinct conformational epitope on native tryptase, suggesting the recombinant proteins were conformationally correct. Each was purified by B2 immunoaffinity chromatography and assessed by Western blotting and immunoassay.

Fig. 5 shows Western blot analyses of $\operatorname{rh} \alpha$ - and $\operatorname{rh} \beta$-tryptase molecules with G5 and G3 mAbs. G3 labels both $\operatorname{rh} \alpha$ - and $\operatorname{rh} \beta$ tryptase molecules with comparable intensities between 10 and $200 \mathrm{ng}$ per lane (Fig. 5 A). In contrast, G5 labels 20-200 ng of $\operatorname{rh} \beta$-tryptase per lane, whereas rh $\alpha$-tryptase is labeled only at the highest amount (Fig. $5 B$ ). Densitometric scanning revealed a staining intensity for $200 \mathrm{ng}$ of rh $\alpha$-tryptase to be comparable to that for $20 \mathrm{ng}$ of $\operatorname{rh} \beta$-tryptase when using the G5 mAb. Also evident in the blots are the presence of two major bands for each rh-tryptase with apparent molecular weights of 31,000 and 30,000 for rh $\alpha$-tryptase and 31,000 and 29,000 for $\operatorname{rh} \beta$-tryptase. This heterogeneity reflects the presence of varying amounts of carbohydrate, because $N$-glycosidase $\mathrm{F}$ treatment results in a single band for each rh-tryptase molecule (13a). Thus, like plasma tryptase from subjects with systemic mastocytosis, the G5 epitope in $\alpha$-tryptase is markedly attenuated.

Fig. 6 shows tryptase dose-response curves for rh $\alpha$ - and $\mathrm{rh} \beta$-tryptase molecules, standardized with purified lung-derived tryptase, using the B12 (Fig. $6 \mathrm{~A}$ ) and G5 (Fig. $6 \mathrm{~B}$ ) immunoassays. Because $50 \mu$ l of sample are typically added to a microtiter well, the dose-response range corresponds to samples containing from $\sim 20$ to $400 \mathrm{ng}$ of tryptase $/ \mathrm{ml}$. The dose-response curves for $\operatorname{rh} \alpha$-tryptase (slope $=1.15)$ and $\operatorname{rh} \beta$-tryptase (1.30) are nearly identical with the B12 immunoassay, each being similar to that obtained with tissue-derived tryptase. In contrast, the slope of the dose-response curve for rh $\alpha$-tryptase $(0.07)$ with the G5 immunoassay is $\sim 10$-fold lower than for $\operatorname{rh} \beta$ tryptase $(0.72)$ and tissue-derived tryptase. Thus, it is likely that the G5 immunoassay is markedly compromised in its ability to detect $\alpha$-tryptase, whereas the B12 assay detects both forms of tryptase equally.

\section{Discussion}

$\alpha$-Tryptase appears to be the predominant form of tryptase in serum or plasma at baseline in both normal subjects and in those with systemic mastocytosis. Like rh $\alpha$-tryptase, tryptase in baseline serum or plasma lacks a high affinity G5 epitope. The low affinity epitope present in rh $\alpha$-tryptase is unlikely to result from incorrect folding of the recombinant protein, because G5 recognizes a linear epitope. Also, both recombinant forms of tryptase exhibit conformational epitopes recognized by the B2, G4, and B12 mAbs, and a linear epitope recognized by G3. Other possible explanations for this finding, such as blocking carbohydrate or removal of the epitope by degradation, were eliminated by showing that removal of carbohydrate did not restore G5 immunoreactivity and that Western blotting with the G5 antibody showed no detectable reduction in electrophoretic mobility compared to tryptase purified from tissue. In contrast, $\beta$-tryptase is the predominant form in preparations that have been purified from mast cells in skin and lung, and in the blood during systemic anaphylaxis. This conclusion was substantiated by measuring rh $\alpha$-tryptase and $\operatorname{rh} \beta$-tryptase in the G5 and B12 immunoassays using purified human lung-derived tryptase as standard. The results indicated that $\operatorname{rh} \beta$-tryptase in both assays and $\operatorname{rh} \alpha$-tryptase in the B12 immunoassay showed identical dose-response profiles to lung tryptase. In the G5 immunoassay, rh $\alpha$-tryptase produced a slope in the dose-response curve $\sim 10$-fold lower than for lung tryptase. Thus, tryptase levels in normal and mastocytosis serum or plasma are higher with the B12 than G5 immunoassays because the former assay measures both $\alpha$ - and $\beta$-tryptase, whereas the latter measures primarily $\beta$-tryptase.

In contrast to serum or plasma tryptase in nonacute subjects, in systemic anaphylaxis tryptase levels are markedly elevated by both tryptase immunoassays (9-11), suggesting that $\beta$-tryp- 

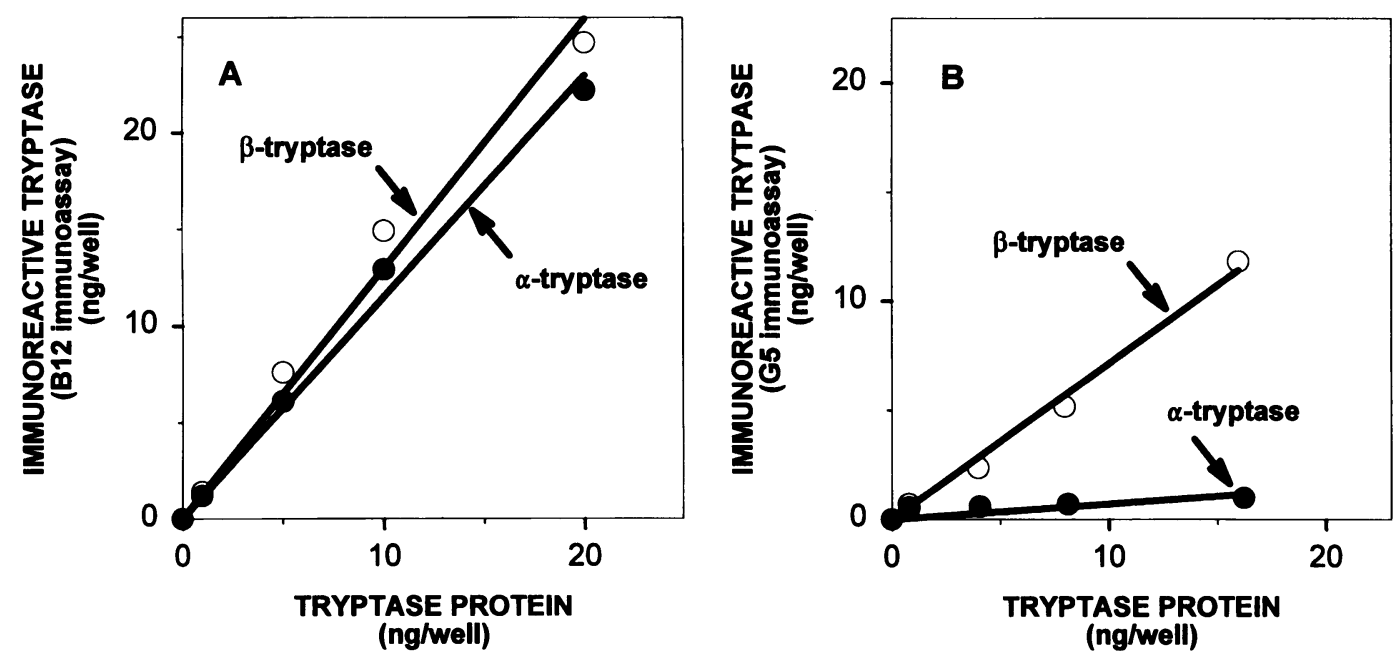

Figure 6. Immunoassay of rh $\alpha$-tryptase and $\operatorname{rh} \beta$-tryptase molecules. Using immunoaffinity-purified human skin-derived tryptase as a standard, $\sim 1-$ $20 \mathrm{ng}$ of $\mathrm{rh} \alpha$ - and $\operatorname{rh} \beta$-tryptase molecules were measured in the B12 (A) and G5 $(B)$ immunoassays. The amounts of rh-tryptase determined by immunoassay against the lung tryptase standard are plotted against the amounts of rh-tryptase determined by a direct protein measurement (bicinchoninic assay).

tase is the predominant form released into the circulation. This is consistent with previous data showing that measurements of tryptase purified from tissue mast cells by the two immunoassays are comparable, and that tryptase in these mast cells is stored primarily in secretory granules. However, mast cells in the skin and in the lung express both $\alpha$-tryptase and $\beta$-tryptase mRNA molecules (16), suggesting that mast cells at each site are capable of producing the corresponding protein products. These data lead to the hypothesis that newly synthesized $\beta$ tryptase is directed to the secretory granule, where it is stored until the cell degranulates, whereas $\alpha$-tryptase is constitutively secreted, and therefore is the predominant type found in blood at baseline. If true, it may be important that the 30 amino acid signal peptides for $\alpha$ - and $\beta$-tryptase molecules differ by three amino acids, which could alter the trafficking patterns through the cytoplasm. This possibility needs to be further studied.

Another consideration is that the rates of production of $\alpha$ tryptase per mast cell may vary among different individuals. For example, among subjects with a history of insect sting anaphylaxis, those destined to have a severe anaphylactic response to an experimental sting challenge had a higher median level of B12-measured tryptase before the challenge than the groups with mild or no systemic response (9). In this circumstance, the elevated baseline level of tryptase may have reflected priming of mast cells rather than increased numbers of mast cells.

A final consideration is whether $\alpha$-tryptase is produced and released by a cell type other than mast cells, one that also is activated or hyperplastic in systemic mastocytosis. Mono-Mac6 cells, a human monocyte cell line (19), expresses only $\alpha$ tryptase mRNA (20). However, neither tryptase mRNA nor tryptase protein have been detected in U937 cells, another monocytic cell line, or in normal monocytes at rest or after activation (20). Basophils from normal peripheral blood also express predominantly $\alpha$-tryptase mRNA, although cellular levels are $\sim 10^{5}$-fold lower than in mast cells (16). Basophilia is not a feature of systemic mastocytosis, and the tryptase protein content of basophils is negligible. Thus, an alternative cell source of $\alpha$-tryptase to mast cells appears to be unlikely.
Among subjects with the diagnosis of mastocytosis, B12measured tryptase levels were markedly elevated in most, but not all subjects, and were at least 10 -fold greater than G5measured tryptase levels. In contrast, when G5-measured tryptase was $\geq 1 \mathrm{ng} / \mathrm{ml}$, and the ratio of B12-measured tryptase to G5-measured tryptase was $<5$, anaphylaxis associated with mast cell degranulation was the most likely diagnosis. Although samples obtained from mastocytosis patients also experiencing anaphylaxis were not examined in the current study; such subjects would be predicted to have elevated G5- and B12-measured tryptase levels and a variable ratio of B12- to G5-measured tryptase depending on the extent of $\beta$-tryptase released by degranulation and the extent of $\alpha$-tryptase present at baseline. In patients with chronic idiopathic urticaria, signs and symptoms appear to involve cutaneous mast cell activation, but not mast cell hyperplasia (21). Consequently, tryptase levels measured with the B12 immunoassay are not elevated compared to healthy controls; and tryptase levels measured with the G5 immunoassay are not detectable ( $\geq 1 \mathrm{ng} / \mathrm{ml}$ ) in most cases, presumably reflecting the localized nature of mast cell degranulation in this condition. Only 1 of the 13 urticaria patients in the current study exhibited a detectable level of tryptase with the G5 immunoassay $(1.9 \mathrm{ng} / \mathrm{ml})$, associated with a level of $5.5 \mathrm{ng} / \mathrm{ml}$ with the B12 immunoassay. Thus, a clinical assessment is needed to correctly interpret tryptase levels.

A preliminary analysis of the diagnostic and prognostic value of these measurements in systemic mastocytosis was performed with the data from the current study. B12-measured levels of plasma tryptase were $<20 \mathrm{ng} / \mathrm{ml}$ in 17 of 46 subjects with indolent mastocytosis and in 0 of the 9 subjects with systemic mastocytosis associated with a hematologic disorder and aggressive mastocytosis. Thus, even though only nine subjects with category II or III disease were available to be studied, the data suggest that a B12-measured tryptase level $<20 \mathrm{ng} / \mathrm{ml}$ indicates category II or III disease is unlikely.

Among those with indolent mastocytosis and a B12-measured tryptase level $<20 \mathrm{ng} / \mathrm{ml}, 10$ subjects were among the 13 diagnosed with only cutaneous involvement; 7 were among the 33 with systemic disease. Only in the patients with cutane- 
ous disease exclusively did a substantial majority have a B12measured tryptase level $<20 \mathrm{ng} / \mathrm{ml}$. Application of Fisher's exact test (when $n<100$ ) to a chi square analysis of the B12measured tryptase data indicate that the risk of systemic disease increases 12-fold when the tryptase concentration is $\geq 20 \mathrm{ng} /$ $\mathrm{ml}\left(P=7.5 \times 10^{-4}\right)$. In some cases where children with urticaria pigmentosa were involved, the low level of tryptase may relate to the self-limited disease typical in these children. Why most subjects with only cutaneous involvement exhibit lower levels of tryptase than the other mastocytosis groups is not known with certainty. One possibility is that the total body burden of mast cells is not dramatically increased in urticaria pigmentosa because only lesional skin shows increased numbers of mast cells (6), and lesions typically cover a minor portion of the total surface area of the skin. Alternatively, for mast cells in the skin compared to noncutaneous sites, $\alpha$-tryptase production may be lower, or once $\alpha$-tryptase is secreted, it may diffuse into the circulation less efficiently.

Three subjects with a nonacute B12-measured tryptase level $>20 \mathrm{ng} / \mathrm{ml}$ were diagnosed to have only cutaneous disease. One $(24 \mathrm{ng} / \mathrm{ml})$ was a 1-yr-old with diffuse cutaneous mastocytosis (positive skin biopsy and negative bone marrow biopsy). Another subject ( $23 \mathrm{ng} / \mathrm{ml}, 43 \mathrm{yr}$ old $)$ had a positive bone marrow biopsy 5 yr before plasma was collected and a negative biopsy at the time of plasma collection. The third subject ( $43 \mathrm{ng} / \mathrm{ml}, 16 \mathrm{yr}$ old $)$ had extensive urticaria pigmentosa and no bone marrow biopsy, yet was classified by clinical criteria as urticaria pigmentosa only. 8 of the 13 patients in this group had a bone marrow biopsy performed near the time of plasma sample collection that was negative for mastocytosis, although two of these also had a prior positive bone marrow biopsy. Thus, a B12-measured tryptase level $>20 \mathrm{ng} / \mathrm{ml}$ in this group suggests either extensive skin involvement, or the possibility of systemic disease that was either unsuspected clinically, or missed by bone marrow biopsy.

In the group of patients with systemic mastocytosis categorized as indolent, clinical severity did not correlate to the B12measured tryptase level. This suggests that clinical severity between patients is not necessarily related to the total body burden of mast cells, but may instead relate to factors such as extent and type of organs involved, the maturity and activation status of the mast cells, associated fibrosis and release of mediators. Among the seven subjects with indolent systemic mastocytosis and a B12-measured tryptase level $<20 \mathrm{ng} / \mathrm{ml}$, one would like to know whether these relatively low levels have prognostic or diagnostic implications. In two of the cases ( 16 and $18 \mathrm{ng} / \mathrm{ml}$ ) the bone marrow biopsy was negative, and the diagnosis of systemic disease was based on a positive bone marrow aspirate. One of these two cases also was HIV-positive. Concentrations of mast cells of the $\mathrm{MC}_{\mathrm{T}}$ type were previously shown to be markedly decreased in biopsies of the small intestine in subjects who died from AIDS (22). However, the HIV-positive patient in the current study did not have advanced disease (CD4 $=1395)$. One patient $(16 \mathrm{ng} / \mathrm{ml})$ had a bone marrow biopsy in which the cell phenotype was uncertain, but thought to be consistent with increased mast cells. Another patient $(11 \mathrm{ng} /$ $\mathrm{ml}$ ) had a bone marrow biopsy 5 yr before obtaining plasma for the current study; raising the possibility that mast cell numbers had regressed. Another patient $(19 \mathrm{ng} / \mathrm{ml})$ had been treated with hydroxyurea for $4 \mathrm{mo}$, suggesting use of this drug to treat indolent systemic mastocytosis should be studied in additional patients. The one other patient receiving this drug in the current study had taken it for $1 \mathrm{mo}$, had a B12-measured tryptase level of $59 \mathrm{ng} / \mathrm{ml}$ and was categorized as having systemic mastocytosis with associated hematologic disorder. The two remaining cases with B12-measured tryptase levels $<20 \mathrm{ng} / \mathrm{ml}$ ( 12 and $17 \mathrm{ng} / \mathrm{ml}$ ) had positive bone marrow biopsies near the time of sample collection, were without other diseases that might affect mast cell numbers, and were not receiving medications that might reduce mast cell numbers.

Patients with systemic mastocytosis associated with hematologic disorder and those with aggressive systemic mastocytosis each had a B12-measured tryptase level $>20 \mathrm{ng} / \mathrm{ml}$. This may reflect the extensive mast cell hyperplasia found in these subjects. Of further interest is the observation that Kit, the receptor for stem cell factor (also called Steel factor, Kit-ligand, and mast cell growth factor), a major growth factor for human mast cells and other hematopoietic cells, carries a mutation that may result in the tyrosine kinase domain being constitutively active in peripheral blood cells obtained from those patients with systemic mastocytosis associated with a hematologic disorder, but not those with indolent or aggressive mastocytosis (23). Thus, different pathogenic pathways may account for the mast cell hyperplasia in these different clinical presentations. Whether sequential tryptase levels in individual mastocytosis patients within any of the categories considered in the current study will have prognostic implication or facilitate evaluation of a therapeutic response will need to be assessed in future studies.

In conclusion, $\alpha$-tryptase appears to be the primary form of human tryptase present in the blood at baseline in both normal subjects and in those with systemic mastocytosis. Consequently, elevated levels of this form of tryptase, which are measurable with the B12 tryptase immunoassay, are found in most patients diagnosed to have systemic mastocytosis. B12-measured tryptase may provide a more precise measure of the total body burden of mast cells than tissue biopsies that assess focal involvement. The B12 assay for $\alpha$-tryptase and $\beta$-tryptase, particularly when performed in conjunction with the G5 assay for $\beta$-tryptase, is a promising screening test for systemic mastocytosis, and may also provide a means to follow disease progression and response to therapeutic interventions.

\section{Acknowledgments}

The authors thank Cheryl Rouse for performing the immunoassays for tryptase.

This work was supported by National Institutes of Health grants AI20487, AI27517, and AI14332, and a grant from Kabi-Pharmacia Diagnostics.

\section{References}

1. Austen, K. F. 1992. Systemic mastocytosis. N. Engl. J. Med. 326:639-640.

2. Metcalfe, D. D. 1991. Classification and diagnosis of mastocytosis: current status. J. Invest. Dermatol. 96:2S-4S.

3. Metcalfe, D. D. 1991. The treatment of mastocytosis: an overview. $J$. Invest. Dermatol. $96: 55 \mathrm{~S}-59 \mathrm{~S}$.

4. Irani, A. A., N. M. Schechter, S. S. Craig, G. DeBlois, and L. B. Schwartz. 1986. Two types of human mast cells that have distinct neutral protease compositions. Proc. Natl. Acad. Sci. USA. 83:4464-4468.

5. Schwartz, L. B., A. M. A. Irani, K. Roller, C. Castells, and N. M. Schechter. 1987. Quantitation of histamine, tryptase and chymase in dispersed human $\mathrm{T}$ and TC mast cells. J. Immunol. 138:2611-2615.

6. Irani, A. A., M. M. Garriga, D. D. Metcalfe, and L. B. Schwartz. 1990 Mast cells in cutaneous mastocytosis: accumulation of the $\mathrm{MC}_{\mathrm{TC}}$ type. Clin. Exp. Allergy. 20:53-58.

7. Castells, M. C., A. M. Irani and L. B. Schwartz. 1987. Evaluation of human peripheral blood leukocytes for mast cell tryptase. J. Immunol. 138:2184-2189. 
8. Enander, I., P. Matsson, J. Nystrand, A.-S. Andersson, E. Eklund, T. R. Bradford, and L. B. Schwartz. 1991. A new radioimmunoassay for human mast cell tryptase using monoclonal antibodies. J. Immunol. Methods. 138:39-46.

9. Schwartz, L. B., T. R. Bradford, C. Rouse, A.-M. Irani, G. Rasp, J. K. Van der Zwan, and P.-W. G. Van Der Linden. 1994. Development of a new, more sensitive immunoassay for human tryptase: use in systemic anaphylaxis. J. Clin. Immunol. 14:190-204.

10. Schwartz, L. B., D. D. Metcalfe, J. S. Miller, H. Earl and T. Sullivan. 1987. Tryptase levels as an indicator of mast-cell activation in systemic anaphylaxis and mastocytosis. N. Engl. J. Med. 316:1622-1626.

11. Van der Linden, P. G., C. E. Hack, J. Poortman, Y. C. Vivié-Kipp, A. Struyvenberg, and J. K. Van der Zwan. 1992. Insect-sting challenge in 138 patients: Relation between clinical severity of anaphylaxis and mast cell activation. J. Allergy Clin. Immunol. 90:110-118.

2. Granerus, G., B. Lönnqvist, and G. Roupe. 1994. No relationship between histamine release measured as metabolite excretion in the urine, and serum levels of mast cell specific tryptase in mastocytosis. Agents Actions. 41 Suppl. C:C127C128.

13. Schwartz, L. B., T. R. Bradford, D. C. Lee, and J. F. Chlebowski. 1990. Immunologic and physicochemical evidence for conformational changes occurring on conversion of human mast cell tryptase from active tetramer to inactive monomer: production of monoclonal antibodies recognizing active tryptase. $J$. Immunol. 144:2304-2311.

13a. Sakai, K., S. D. Long, D. A. D. Pettit, G. A. Cabral, and L. B. Schwartz. 1995. Expression and purification of recombinant human tryptase in a baculovirus system. Protein Expr. Purif. In press.

14. Schwartz, L. B. 1985. Monoclonal antibodies against human mast cell tryptase demonstrate shared antigenic sites on subunits of tryptase and selective localization of the enzyme to mast cells. J. Immunol. 134:526-531.

5. Smith, P. K., R. I. Krohn, G. T. Hermanson, A. K. Mallia, F. H. Gartner, M. D. Provenzano, E. K. Fujimoto, N. M. Goeke, B. J. Olson, and D. C. Klenk. 1985. Measurement of protein using bicinchoninic acid. Anal. Biochem. 150:7685.
16. Xia, H.-Z., C. L. Kepley, K. Sakai, J. Chelliah, A.-M. A. Irani, and L. B. Schwartz. 1995. Quantitation of tryptase, chymase, Fc $\epsilon$ RI $\alpha$, and Fc $\epsilon$ RIgamma mRNAs in human mast cells and basophils by competitive reverse transcriptionpolymerase chain reaction. $J$. Immunol. 154:5472-5480.

17. Miller, J. S., E. H. Westin, and L. B. Schwartz. 1989. Cloning and characterization of complementary DNA for human tryptase. J. Clin. Invest. 84:11881195.

18. Miller, J. S., G. Moxley, and L. B. Schwartz. 1990. Cloning and characterization of a second complementary DNA for human tryptase. J. Clin. Invest. 86:864-870.

18a. Vanderslice, P., S. M. Ballinger, E. K. Tam, S. M. Goldstein, C. S. Craik, and G. H. Caughey. 1990. Human mast cell tryptase: multiple cDNAs and genes reveal a multigene serine protease family. Proc. Natl. Acad. Sci. USA. 87:38113815 .

19. Ziegler-Heitbrock, H. W., E. Thiel, A. Futterer, V. Herzog, A. Wirtz, and G. Riethmuller. 1988. Establishment of a human cell line (Mono Mac 6) with characteristics of mature monocytes. Int. J. Cancer. 41:456-461.

20. Huang, R., M. Åbrink, A. E. Gobl, G. Nilsson, M. Aveskogh, L. G. Larsson, K. Nilsson, and L. Hellman. 1993. Expression of a mast cell tryptase in the human monocytic cell lines U-937 and Mono Mac 6. Scand. J. Immunol. 38:359-367.

21. Smith, C. H., C. Kepley, L. B. Schwartz, and T. H. Lee. 1995. Mast cell number and phenotype in chronic idiopathic urticaria. J. Allergy Clin. Immunol. 96:360-364.

22. Irani, A. M., S. S. Craig, G. DeBlois, C. O. Elson, N. M. Schechter, and L. B. Schwartz. 1987. Deficiency of the tryptase-positive, chymase-negative mast cell type in gastrointestinal mucosa of patients with defective $\mathrm{T}$ lymphocyte function. J. Immunol. 138:4381-4386.

23. Nagata, H., A. S. Worobec, C. K. Oh, S. Tannenbaum, Y. Suzuki, and D. D. Metcalfe. 1995. Identification of a point mutation in the catalytic domain of the proto-oncogene c-kit in peripheral blood mononuclear cells of patients who have mastocytosis with an associated hematologic disorder. Proc. Natl. Acad. Sci. USA. 92:10560-10564. 